Małgorzata Jedynak

Uniwersytet Wrocławski

\title{
INICJATYWY RADY EUROPY I KOMISJI EUROPEJSKIEJ NA RZECZ WSPIERANIA REFLEKSYJNOŚCI NAD PROCESEM UCZENIA SIĘ I NAUCZANIA JĘZYKA OBCEGO
}

\author{
Council of Europe and European Commission initiatives supporting \\ reflection on foreign language learning and teaching processes
}

In the era of globalisation a command of foreign languages is regarded as a priority. For this reason, the Council of Europe and the European Commission promote language learning and linguistic diversity. A focal point in their language policy is reflection, which is recognized as a key feature of an employee's professionalism. Therefore, the importance of reflection is stressed throughout all the years of language education. The objective of this paper is to give information about the documents, tools and actions which support a reflective approach to language learning and teaching in Europe.

Keywords: reflection in language education, Council of Europe documents, European Commission initiatives, CEFR, FREPA, ELP, Autobiography of Intercultural Encounters, Lifelong Learning Programme

Słowa kluczowe: refleksja w edukacji językowej, dokumenty Rady Europy, inicjatywy Komisji Europejskiej, ESOKJ, FREPA, EPJ, Autobiografia Spotkań Międzykulturowych, Program Uczenie się przez całe życie

\section{Wstęp}

W dzisiejszych czasach uczenie się języka obcego postrzega się nie tylko w kategoriach, które są widoczne i łatwe do zmierzenia, jak na przykład osiągnięcia w kompetencji komunikacyjnej mierzone za pomocą różnych testów. 
Coraz częściej kładzie się nacisk na te elementy uczenia się języka obcego, które nie są tak łatwo zauważalne i trudniejsze do zmierzenia, jak na przykład gotowość komunikacyjna, zaangażowanie w proces uczenia się, tolerancja dwuznaczności, chęć podejmowania ryzyka, zrozumienie swojej tożsamości kulturowej, czy refleksyjność nad procesem uczenia się.

Umiejętność refleksji traktuje się obecnie jako istotny cel kształcenia zarówno uczniów jak i nauczycieli. W Polsce znajduje to odzwierciedlenie w oczekiwanych efektach kształcenia, zawartych w podstawie programowej określonej w rozporządzeniu Ministra Edukacji Narodowej z dnia 23 grudnia $2008^{1}$ oraz standardach kształcenia przygotowującego do wykonywania zawodu nauczycieli, określonych w rozporządzeniu Ministra Nauki i Szkolnictwa Wyższego z dnia 17 stycznia $2012^{2}$.

Promowanie refleksyjności dotyczy nie tylko polskiej rzeczywistości edukacyjnej. Zarówno Rada Europy, jak i Komisja Europejska uważają refleksję za jeden z priorytetów europejskiej polityki językowej. Rada Europy przyczynia się do rozwijania refleksyjności poprzez inicjowanie różnorodnych działań opracowywanych przez dwie instytucje, to znaczy Wydział Polityki Językowej (WPJ) w Strasburgu oraz Europejskie Centrum Języków Nowożytnych (ECJN) w Grazu. Ta pierwsza opublikowała szeroko rozpowszechnione dokumenty dla krajów członkowskich, takie jak Europejski System Opisu Kształcenia Językowego (ESOKJ) czy Europejskie Portfolio Językowe (EPJ) oraz dokumenty od niedawna funkcjonujące w nauczaniu języków, takie jak System Opisu Pluralistycznych Podejść do Języków i Kultur (FREPA), czy Autobiografia Spotkań Międzykulturowych. Natomiast ECJN skupia się na praktycznej stronie uczenia i nauczania języków, chociaż ma również swój udział w tworzeniu dokumentów takich jak FREPA. W ramach działalności ECJN nauczyciele z krajów członkowskich mogą brać udział w różnych spotkaniach, warsztatach oraz projektach, a ich obserwacje i wnioski są często źródłem rekomendacji dla pozostałych krajów członkowskich, a czasami stają się przedmiotem analizy w publikacjach ECJN. Z kolei Komisja Europejska promuje refleksyjność głównie poprzez oferowane programy mobilnościowe dla uczniów i nauczycieli, takie jak Erasmus, Comenius, czy wizyty studyjne, oraz rozpowszechnianie raportów, wyników badań i ankiet w formie ogólnodostępnych publikacji.

${ }^{1}$ Podstawa programowa określona w rozporządzeniu Ministra Edukacji Narodowej z dn. 23.12.2008r. w sprawie podstawy programowej wychowania przedszkolnego oraz kształcenia ogólnego w poszczególnych typach szkół. Dz.U. z 2009 r. nr 4, poz. 17.

${ }^{2}$ Rozporządzenie MNiSW z dn. 17.01.2012 r. w sprawie standardów kształcenia przygotowującego do wykonywania zawodu nauczycieli. DzU Nr 164, poz. 1365. 
Niniejszy artykuł ma charakter informacyjny. Jego głównym celem jest wskazanie na inicjatywy europejskie, które przyczyniają się do rozwijania refleksji w uczeniu się i nauczaniu języków obcych. Najpierw przybliżę zagadnienie refleksyjności, starając się odpowiedzieć na pytanie, skąd wzięło się zainteresowanie refleksją w europejskim szkolnictwie, szczególnie w kontekście uczenia się języków obcych (JO). Następnie omówię najważniejsze działania Rady Europy i Komisji Europejskiej promujące refleksyjność zarówno w postawach uczniów, jak i nauczycieli.

\section{Refleksyjność a uczenie się i nauczanie języków obcych}

W ostatnich dwóch dekadach pojawiło się wiele publikacji z zakresu dydaktyki nauczania języków obcych, których autorzy zwracają uwagę na rolę refleksyjności w uczeniu się (np. Adams-Tukiendorf, 2012; Farrell, 2007; Smith i Lennon, 2011). Wiele badań glottodydaktycznych w zakresie refleksyjności dotyczy wykorzystywania strategii uczenia się podczas nabywania różnych aspektów języka (np. Pawlak, 2010; Rokoszewska, 2012).

Nasuwa się pytanie, skąd bierze się tak duże zainteresowanie refleksyjnością - problemem, który do lat 90. ubiegłego stulecia nie był przedmiotem dyskusji wśród dydaktyków. Wydaje się, że odpowiedzi na ten temat należy szukać w dążeniach jednoczącej się Europy do zwiększenia profesjonalizmu pracownika poprzez rozwijanie jego kompetencji, w tym jego refleksyjności, już na wczesnym etapie edukacji. Refleksyjny uczeń JO ma szansę zostać w przyszłości profesjonalnym pracownikiem, który potrafi uczyć się na podstawie własnych doświadczeń. Europejski system kształcenia korzysta z wiedzy na temat refleksji pochodzącej nie tylko ze współczesnych badań naukowych, ale również ze starszych źródeł opracowanych przez chińskich i greckich myślicieli. Zarówno Konfucjusz jak i Platon czy Arystoteles zauważyli, że w uczeniu się istotną rolę odgrywa refleksja nad wcześniejszymi doznaniami i doświadczeniami. Koncepcja myślenia i działania refleksyjnego została zaadoptowana do dydaktyki nauczania JO z psychologii. Dewey (1933/2007) postrzegał refleksję jako dalszy wymiar racjonalnego myślenia i uzasadniał potrzebę kształcenia w kierunku jej rozwijania. Schön (1987) z kolei udowadniał, że zastosowanie teorii w praktyce pociąga za sobą tzw. refleksję retrospektywnq (z ang. reflection on action), będącą wynikiem analizy doświadczenia, oraz refleksję $w$ działaniu (z ang. reflection in action), będącą częścią aktywnego myślenia. Boud i Walker (1998), traktując refleksję jako czynność holistyczną, uzupełnili powyższe teorie o czynnik emocjonalnej subiektywności. Powyższe trzy podejścia 
do refleksji znalazły swoje zastosowanie w nauczaniu języków obcych promowanych w europejskim systemie szkolnictwa.

W literaturze na temat dydaktyki nauczania JO refleksyjność jest postrzegana jako zdystansowanie się wobec danej sytuacji poprzez przyjęcie krytycznej postawy, dążenie do wszechstronnej analizy problemu oraz poszukiwanie efektywnych rozwiązań po wcześniejszym rozważeniu mocnych i słabych stron postawy własnej lub innych osób (Kohonen, 2000). Utożsamia się ją z procesem wywołanym przez zmianę świadomości ucznia lub nauczyciela na trzech poziomach: 1) świadomości związanej z zadaniem, 2) świadomości związanej z osobowością oraz 3) świadomości związanej z procesem i kontekstem uczenia się (Arnold, 1998). Pierwszy typ świadomości polega na zrozumieniu systemu języka obcego i nauczeniu się koniecznych umiejętności komunikatywnych wraz z meta-językową wiedzą dotyczącą różnych poziomów opisu języka. Drugi rodzaj świadomości wiąże się ze zmianą tożsamości np. kulturowej, poczucia własnej wartości, ukierunkowania własnych działań, oraz rozwojem zachowań autonomicznych. Ostatni poziom świadomości odnosi się do zarządzania procesem uczenia się w taki sposób, aby był on lepiej zorganizowany. Tego typu świadomość wiąże się z zastosowaniem metakognitywnej i strategicznej wiedzy w celu przeprowadzenia samooceny procesu uczenia się (Kohonen, 2000: 2).

Nie należy jednak zapominać, że sama świadomość nie wystarczy, aby doszło do refleksyjności. Najważniejszym elementem jest bowiem chęć zmiany, która niewątpliwie wymaga motywacji do podjęcia realnych kroków realizujących nowe pomysły (Farrell, 2007 w Adams-Tukiendorf, 2012: 15). Na silny związek pomiędzy refleksyjnością, a wewnętrzną motywacją do działania wskazuje również Dörnyei (2001). Podczas procesu nauki lub nauczania, refleksyjny uczeń lub nauczyciel dokonują wglądu w siebie, co pozwala na odkrywanie własnego potencjału postrzeganego zarówno w kategoriach kognitywnych, jak i emocjonalnych. Interesujące spojrzenie na problem refleksyjności prezentuje Whitmore (2002), który podkreśla jej ścisły związek z odbudowywaniem własnej wartości. Niewątpliwie zarówno motywacja, jak i poczucie własnej wartości są istotnymi czynnikami w procesie uczenia się i nauczania JO, często określanymi jako determinanty sukcesu.

Refleksyjność w uczeniu się i nauczaniu języka obcego może być rozwijana na wiele sposobów. Najczęściej stosuje się krytyczną analizę w formie samooceny procesu nauki w przypadku uczniów, lub procesu dydaktycznego w przypadku nauczycieli. Do innych form wykorzystywanych do promowania 
refleksji należą pisanie pamiętnika oraz dyskusje w grupach. ${ }^{3}$ Wspomniane powyżej formy znajdują swoje odzwierciedlenie w dokumentach z zakresu nauczania języków obcych (np. EPJ dla uczniów i nauczycieli) oraz programach (np. „Uczenie się przez całe życie”) rozwijających refleksję poprzez działanie osadzone w praktyce, o którym pisał Schön.

\section{Refleksyjność w dokumentach Rady Europy}

Należy zauważyć, że wszystkie dokumenty opracowane przez Radę Europy w odniesieniu do uczenia się JO wymagają od odbiorców refleksyjności. Prawidłowe stosowanie dokumentów nie jest możliwe bez przyjęcia krytycznej postawy, wszechstronnej analizy i selektywnego podejście do treści. W niniejszym punkcie skupię się najpierw na omówieniu, w jaki sposób koncepcja refleksyjności jest realizowana w dokumentach opisowych tzn. w Europejskim Systemie Opisu Kształcenia Językowego (ESOKJ) oraz Systemie Opisu Pluralistycznych Podejść do Języków i Kultur (FREPA). ${ }^{4}$ Następnie pokażę, w jaki sposób refleksyjność jest promowana w dokumentach przeznaczonych, takich jak Europejskie Portfolio Językowe (EPJ) i Autobiografia Spotkań Międzykulturowych.

Należy zauważyć, że mimo że zakres tematyczny dokumentów opisowych jest odmienny (ESOKJ dotyczy kompetencji językowych, a FREPA kompetencji międzykulturowych i różnojęzyczności), cele tych dwóch dokumentów są zbieżne tzn. dążą do rozwijania indywidualnej refleksyjności u użytkowników. Zarówno ESOKJ, jak i FREPA rozwijają refleksyjność w dwóch obszarach, takich jak nauczanie i uczenie się, powiązanych oczywiście z ocenianiem i samooceną.

Jeśli chodzi o obszar nauczania ESOKJ to nauczyciele JO, autorzy programów nauczania lub autorzy podręczników korzystający z tego dokumentu powinni dobrać treści nauczania w taki sposób, aby zrealizować odpowiednie cele w zakresie rozwijania sześciu sprawności językowych. ESOKJ jako dokument otwarty, elastyczny i przyjazny dla użytkowników jest jednak dokumentem opisowym, a nie normatywnym narzucającym gotowe treści (Tranter,

\footnotetext{
${ }^{3}$ Adams-Tukiendorf (2012) w swoim artykule wspomina o mniej znanej formie rozwijania refleksji, a mianowicie grach motywujących do myślenia z meta poziomu. Autorka zauważa, że udział w tego typu grach pozwala „docenić rolę samoświadomości własnych schematów myślenia, reagowania i działania, włącza nowe potencjały percepcyjne i poznawcze oraz motywuje do wykorzystania produktu refleksji, czyli wglądu w siebie, do działania i wprowadzenia konstruktywnych zmian" (2012: 24).

${ }^{4}$ W przeciwieństwie do polskiego akronimu ESOKJ, w polskiej literaturze przyjął się anglojęzyczny akronim FREPA ( $z$ ang. The Framework of Reference for Pluralistic Approaches to Languages and Cultures).
} 
2003). Proponuje on tylko przemyślenie pewnych kwestii takich jak np. indywidualne potrzeby uczących się, sposób oceniania lub kontekst, w którym mogą pojawić się zadania komunikacyjne. ESOKJ inicjuje szereg refleksyjnych pytań, które mogą postawić sobie jego użytkownicy. Pytania te powinny z czasem doprowadzić do procesów ukierunkowanych na działanie, przygotowujących do rozwiązania problemów związanych z nauczaniem i uczeniem się języków. Jeśli chodzi o instytucje zajmujące się nauczaniem JO oraz autorów programów nauczania, pytania te mogą wyglądać następująco: $W$ jakich sytuacjach i domenach życia uczniowie będq chcieli wykorzystywać JO?, W jaki sposób należy je uwzględnić w programach nauczania?, W jaki sposób będq planować treści realizowane według poziomu kompetencji ESOKJ?, W jaki sposób poszczególne poziomy znajdq swoje odzwierciedlenie w programach nauczania języka?, W jaki sposób odpowiedzi uzyskane na powyższe dwa pytania będq kształtowały zarówno cele nauczania jak i selekcję materiałów do zajęć?, W jaki sposób nauczyciele będq zaznajamiani z treściami ESOKJ?

ESOKJ pełni również ważną rolę w podnoszeniu świadomości nauczycieli JO w zakresie znaczenia indywidualnych cech uczącego się i ich wpływu na naukę. Efektem refleksji u nauczycieli będzie zatem wdrażanie metod i technik nauczania odpowiadających indywidualnym potrzebom uczniów. Zatem spojrzenie refleksyjne na ESOKJ może zaowocować takimi pytaniami jak: Jakie powinny być cele mojego nauczania, aby realizować poziomy kompetencji wynikajqce z ESOKJ?, W jaki sposób mogę dostosować mój sposób uczenia oraz moje materiały dydaktyczne, tak aby realizować komunikatywny cel zajęć wynikajacy z ESOKJ?, W jaki sposób określony przeze mnie sposób nauczania i moje materiały dydaktyczne wpłynq na ocenianie podczas zajęć?

Jak wspomniałam wcześniej, ESOKJ jest dokumentem otwartym, co wymaga od wspomnianych powyżej dwóch grup użytkowników zarówno dużej refleksyjności przejawiającej się w samodzielnej krytycznej analizie treści ESOKJ, świadomości potrzeb docelowej grupy uczniów oraz selekcji odpowiednich treści nauczania. Niestety z obserwacji autorki wynika, że wiele instytucji zajmujących się nauczaniem języków obcych, nie potrafi refleksyjnie spojrzeć na ESOKJ. Przejawia się to najczęściej w dążeniu w kierunku pełnego wdrażania wytycznych ESOKJ, które w konsekwencji prowadzi do częściowego lub całkowitego zrezygnowania ze stosowania dokumentu.

Jeśli chodzi o obszar uczenia się, ESOKJ zaowocował wprowadzeniem dwóch kategorii, od których w efekcie zależy powodzenie nauki, a mianowicie indywidualnych cech ucznia oraz opanowania umiejętności uczenia się. Ta druga kategoria ma swoje odzwierciedlenie we wprowadzeniu nowej kompetencji nazywanej kompetencją uczenia się ( $z$ ang. learning to learn). Jak zauważa Komorowska (2007: 315), „nie sposób nauczyć tego, co okaże się przydatne, 
gdyż nie wiadomo, co owa przydatność konkretnie oznacza". Z tego powodu zaczęto rozwijać takie cechy ucznia jak samodzielność w docieraniu do wiedzy, wykorzystywanie umiejętności językowych poza klasą, poszukiwanie własnego stylu uczenia się oraz efektywnych strategii uczenia się i komunikowania w JO. Wszystkie te cechy związane są ściśle z umiejętnością refleksji nad procesem uczenia. Zatem spojrzenie refleksyjne na ESOKJ u tego typu użytkowników może zaowocować takimi pytaniami jak: W jaki sposób mogę osiq̨gnać cele, aby zrealizować poszczególne poziomy kompetencji ESOKJ (jakie zadania, ćwiczenia i strategie sq odpowiednie)? W jaki sposób mogę ustalić swój poziom biegłości na podstawie ESOKJ(jakie testy mogę zastosować)?, W jaki sposób i z jakimi tematami będę sobie musiał/musiała poradzić?, W jakich warunkach będzie przebiegało moje uczenie?

Zakres i charakter pytań jakie zadadzą sobie powyżej wspomniane grupy użytkowników zależy tylko od nich samych. Użytkownicy mają zatem szerokie pole do interpretacji wskazówek podanych w ESOKJ, czasami ich modyfikacji podyktowanych konkretną sytuacją i mogą, lecz nie muszą, rozważyć sugestie podane przez twórców dokumentu. Ma to swoje odzwierciedlenie w stwierdzeniu, które wielokrotnie pojawia się w ESOKJ (2003: 32, 59): „użytkownicy Europejskiego systemu opisu kształcenia językowego mogą rozważyć i jeśli uznają za stosowne określić".

Narzędziem edukacyjnym ściśle powiązanym z ESOKJ jest Europejskie Portfolio Językowe (EPJ), które pozwala uczniowi na zaprezentowanie swoich umiejętności językowych i doświadczeń międzykulturowych z różnych okresów nauki we wszystkich znanych mu językach. Zastosowanie EPJ w klasie pomaga kształtować umiejętności bazujące na krytycznej refleksji nad własnymi sposobami uczenia się języków, celami nauki oraz indywidualnymi potrzebami. Warto zaznaczyć, że to uczeń, a nie nauczyciel decyduje jakie informacje będzie zawierać jego Portfolio. Nie umniejsza to jednak roli nauczyciela, który przedstawiając EPJ uczniowi, zapoznając go ze sposobami pracy z dokumentem na lekcji lub w domu, przyczynia się do stymulowania refleksji ucznia. Istnieje również wersja EPJ dla przyszłych nauczycieli, która stanowi narzędzie refleksji nad procesem nauczania.

Przyjrzyjmy się teraz dokumentowi opisowemu, który stanowi uzupełnienie ESOKJ, jakim jest FREPA. Zawiera on również deskryptory, które występowały w ESOKJ, ale dotyczą one ogólnych kompetencji ucznia w zakresie różnych języków i kultur, a nie tylko jednego języka traktowanego jako odrębny system. To dokument, który otwiera uczniów na różnojęzyczność i międzykulturowość oraz wyposaża ich w umiejętności uczenia się języków. Otwarcie na języki i kultury nie byłoby jednak możliwe bez refleksyjnego spojrzenia na nie. Struktura dokumentu, podobnie jak w przypadku ESOKJ 
charakteryzuje się ogólnością, elastycznością i otwartością, co pozwala użytkownikom na krytyczną analizę treści dokumentu. Jest to wyraźnie zaakcentowane w Części 2 FREPA (Tabela ogólnych kompetencji), w której kompetencje dotyczące języków i kultur oraz związku pomiędzy nimi są określane jako te, które powinny „aktywować wiedzę, umiejętności oraz poglądy poprzez refleksję i działanie" (Candelier et al., 2012: 20). Część 3 dokumentu stanowi zbiór zasobów z zakresu wiedzy (savoir), postaw (savoir-etre) i umiejętności (savoir-faire) - trzech elementów rozwijanych w ramach podejścia pluralistycznego. Zbiór nie jest jednak zamknięty i stanowi jedynie propozycje wyznaczników biegłości potrzebnych do rozumienia kompetencji różnojęzycznej i międzykulturowej. Jak zauważają Candelier i Schröder-Sura (2012: 7), wyznaczniki biegłości można stosować na wiele sposobów w celu promowania nauczania różnojęzycznego i międzykulturowego. Użytkownicy mogą uzupełnić go o własne wyznaczniki lub selektywnie podejść do gotowych rozwiązań oferowanych przez dokument.

Grupą docelową dokumentu FREPA są nauczyciele JO oraz innych przedmiotów, trenerzy nauczycieli, metodycy, decydenci, a także autorzy podręczników i programów nauczania. Nauczyciele i metodycy mają dodatkowo do swojej dyspozycji internetową bazę danych FREPA z materiałami dydaktycznymi w różnych językach, które rozwijają wiedzę, postawy i umiejętności w zakresie podejścia pluralistycznego. ${ }^{5}$ Na przykład, w celu podniesienia świadomości uczniów na temat różnorodności systemów fonologicznych, nauczyciel może wybrać materiały prezentujące onomatopeiczne dźwięki wydawane przez zwierzęta w różnych językach. Jednak nie wszyscy uczniowie będą wykazywali zainteresowanie tym tematem. Dlatego korzystanie z tej bazy powinno być selektywne, kierowane dostosowaniem zasobów dydaktycznych do kontekstu, potrzeb uczniów oraz ich poziomu. Łączy się to oczywiście z krytyczną analizą materiałów oraz odkrywaniem ich braków, a więc elementami stanowiącymi filary podejścia refleksyjnego. Jakie pytania mogą pojawić się u refleksyjnych użytkowników FREPA? Niewątpliwie te związane z planowaniem treści, które mogłyby brzmieć następująco: Jakie cele należy sformułować $w$ dziedzinach zwiqzanych $z$ różnojęzycznościq i międzykulturowościq̨?, Jakie istniejq podobieństwa między językami obcymi nauczanymi w szkole i językami szkoły (językami rodzimymi)?, W jaki sposób można otworzyć uczniów na inne języki i kultury (jakie treści, jakie zadania)? W jaki sposób można najlepiej zintegrować w nauczaniu działania służqce promowaniu różnojęzyczności i uczeniu się międzykulturowości?, W jaki spo-

${ }^{5}$ Materiały dla nauczycieli są dostępne na stronie http://carap.ecml.at. 
sób można praktycznie zastosować kompetencje różnojęzyczne oraz międzykulturowe, jak również kompetencje ułatwiajq̨ce uczenie się języków?

Dokument FREPA powinien być stosowany razem z przypisanym mu praktycznym narzędziem edukacyjnym tzn. Autobiografiq spotkań międzykulturowych, która jest przeznaczona dla wsparcia i zachęcenia uczniów do rozwijania kompetencji międzykulturowych. Autobiografia zawiera szereg pytań dotyczących konkretnych spotkań międzykulturowych, powiązanych z różnymi kompetencjami. Dotyczą one jedenastu różnych elementów dialogu międzykulturowego np. tolerancji dla niejednoznaczności, empatii, świadomości komunikacyjnej, orientacji nastawionej na działanie, czy krytycznej świadomości kulturowej. ${ }^{6}$ Autorzy dokumentu zaznaczają, że nie ma obowiązku odpowiadania na wszystkie pytania, i to uczeń podejmuje samodzielnie decyzję, na które pytania chce odpowiedzieć. Jego decyzja wymaga więc refleksyjnej pracy, podczas której uczeń dokonuje wyboru różnych wydarzeń kulturowych ze swojego życia, a następnie ich krytycznej analizy. Ponowne zastosowanie Autobiografii po jakimś czasie pozwala uczniowi spojrzeć na różne wydarzenia międzykulturowe z dystansu i zastanowić się, czy i w jakim stopniu jego ocena tych wydarzeń uległa zmianie.

Jak widać, Autobiografia nie tylko stymuluje krytyczną refleksję nad własnymi reakcjami i postawami wobec doświadczeń z innymi kulturami, ale również ułatwia świadome podejmowanie decyzji w procesie uczenia się JO. Niestety nauczyciele rzadko stosują to narzędzie edukacyjne $w$ klasie, co wynikać może z braku znajomości Autobiografii lub braku czasu na wdrażanie aspektów międzykulturowych w czasie zajęć językowych.

\section{Refleksyjność w Programach Komisji Europejskiej}

Komisja Europejska, podobnie jak Rada Europy, również propaguje naukę języków obcych. Znalazło to odzwierciedlenie w Strategii na rzecz inteligentnego i zrównoważonego rozwoju sprzyjajqcego włączeniu społecznemu UE 2020, będącej długofalowym programem społeczno-gospodarczym, w którym zakłada się wzrost oparty na wiedzy, również tej związanej z nauką języków obcych i różnorodnością językową. To z kolei przyczynia się do zwiększenia mobilności i możliwości zatrudnienia na terenie Unii. Jak już wspomniałam w punkcie 2, Unia Europejska zdaje sobie sprawę jak ważną kompetencją

\footnotetext{
${ }^{6}$ Inne kompetencje rozwijane w Autobiografii to szacunek dla inności, uznanie tożsamości, umiejętność odkrywania i interakcji, elastyczność w zachowaniu, świadomość procesów komunikacji, umiejętności interpretowania i odnoszenia się (dostrzeganie różnic i podobieństw).
} 
u pracownika jest jego krytyczna refleksyjność, którą uważa się za element składowy profesjonalizmu. Dlatego też dąży do rozwijania refleksyjności we wszystkich obszarach edukacji, w tym w nauczaniu języków. Cel ten realizowany jest poprzez wdrażanie różnorodnych programów i działań.

Jednym z takich programów jest Program „Uczenie się przez całe życie” (z ang. Lifelong Learning), którego głównym zadaniem jest promowanie wymiany, współpracy oraz mobilności pomiędzy systemami edukacji i szkolenia we wszystkich krajach UE. Celem nadrzędnym programu jest przyczynienie się do wzrostu jakości kształcenia i szkolenia w UE. W Polsce do końca 2013 roku w ramach Programu „Uczenie się przez całe życie” realizowano takie programy jak Comenius, Erasmus, Leonardo da Vinci, Grundtvig, e-Twinning, European Language Label, Młodzież w Działaniu, Polsko-Litewski Fundusz Wymiany Młodzieży oraz Wizyty Studyjne. ${ }^{7}$ Głównym filarem powyższych programów jest wymiana doświadczeń, nawiązywanie nowych kontaktów oraz krytyczna refleksja, która ma prowadzić do wdrażania przez uczestników programów zmian o charakterze indywidualnym lub instytucjonalnym. Udział w programach pozwala również na wprowadzenie innowacyjnych rozwiązań w systemie edukacji, w tym w kształceniu językowym.

O tym, jak ważnym elementem powyższych programów jest refleksyjność, świadczy coroczny konkurs EDUinspiracje koordynowany w Polsce przez FRSE (Fundację Rozwoju Systemu Edukacji), która ma na celu wyłonienie projektów nazywanych mianem dobrych praktyk. Przyjrzyjmy się refleksjom jednej z laureatek konkursu w 2008 roku, która uczestniczyła w wizycie studyjnej na temat podejścia CALL w środowisku dwujęzycznym:

Decyzja o realizacji wizyty studyjnej wywarła ogromny wpływ na mnie i moje otoczenie. Jako nauczyciel języka obcego podniosłam swoje kwalifikacje zawodowe - merytoryczne i językowe. Nauczyłam się, że dużo jest w zasięgu moich możliwości - zaczęłam aktywnie korzystać z oferty edukacyjnych programów Unii Europejskiej. (...) Po powrocie z wizyty studyjnej podzieliłam się swoimi spostrzeżeniami i wiedzą z gronem pedagogicznym, a w głowie zaczął mi kiełkować pomysł na zajęcia dla moich uczniów, rozwijające zarówno moje, jak i ich zainteresowania oraz pasje. (EDUinspiracje, 2013)

W powyższej wypowiedzi widać wyraźnie, jak refleksyjne podejście i świadomość wartości dodanej do dotychczasowej praktyki zawodowej doprowadziły do powstania pomysłu. Obecnie pomysł ten został przekształcony

${ }^{7}$ Od 1 stycznia 2014 roku Program „Uczenie się przez całe życie” został zastąpiony programem Erasmus+. 
w konkretne działanie, a mianowicie prowadzenie zajęć pozalekcyjnych w szkole z zakresu nauk ścisłych w języku angielskim (Science English).

Poziom refleksyjności uczestnika jest czynnikiem, który w znacznej mierze decyduje o sukcesie wizyty studyjnej. ${ }^{8}$ Już na etapie wyboru tematu wizyty spośród kilkudziesięciu lub kilkuset propozycji, przyszły uczestnik musi przeanalizować potrzeby zarówno własne jak i instytucji, którą reprezentuje. Dodatkowo musi dokonać analizy własnych kompetencji zarówno językowych, jak i zawodowych, aby dokonać trafnego wyboru tematu z katalogu wizyt studyjnych publikowanych corocznie przez Komisję Europejską. Refleksyjność jest również niezbędna na etapie tworzenia wspólnego raportu przez wszystkich uczestników pod koniec wizyty studyjnej. Znalazło to swoje odzwierciedlenie w standardowym raporcie grupowym opracowanym przez Europejskie Centrum Rozwoju Doskonalenia Zawodowego (Cedefop), w którym znajduje się polecenie „opisz przykłady dobrych praktyk, z którymi zaznajomiłeś się podczas wizyty studyjnej (zarówno w instytucji przyjmującej uczestników jak i od uczestników z innych państw)". Końcowy raport składany przez uczestników do swojej Narodowej Agencji również wymaga krytycznej refleksji polegającej na wszechstronnej analizie wizyty studyjnej (działania przygotowawcze, opis wizyty, działania po zakończeniu wizyty), skupieniu się na jej mocnych i słabych stronach (wpływ na rozwój osobisty i zawodowy, wiedzę i umiejętności, instytucję macierzystą i środowisko lokalne) oraz zaproponowaniu sposobów usprawnienia wizyty.

Przyjrzyjmy się teraz kilku wybranym refleksjom laureatów EDUinspiracji w kategorii European Language Label (ELL).

Dzięki projektom łączącym naukę języka i teatr zaistniałam w środowisku jako osoba, która robi coś nowego, która w niekonwencjonalny sposób podchodzi do swojej pracy. (...) Zbliżam się powoli do końca mojej zawodowej drogi, ale nadal będę propagować naukę języka francuskiego przez sztukę. (Projekt „,Wykorzystywanie technik teatralnych w nauczaniu języka francuskiego" laureat w konkursie indywidualnym dla nauczycieli w 2011 roku, EDUinspiracje 2013)

Mieliśmy jednocześnie nadzieję, że spopularyzowanie podejścia deDOMO wśród rodziców będzie stopniowo oddziaływać pozytywnie także na praktykę nauczania języka obcego w środowisku szkolnym, przesuwając nacisk z poprawności językowej na sukces komunikacyjny, choćby częściowy, a także na wspieranie, a nie

\footnotetext{
${ }^{8}$ Wizyty studyjne są realizowane w Polsce przez FRSE jako jedno z działań programu międzysektorowego. Podczas krótkich 3-5 dniowych spotkań spotykają się przedstawiciele z różnych krajów w Europie, którzy specjalizują się w podobnych obszarach edukacji, w tym językowej, kształcenia i doskonalenia zawodowego.
} 
ocenianie prób użycia języka przez ucznia, nawet jeśli są one na razie formalnie niedoskonałe. (Projekt „deDOMO Angielski dla rodziców (i dzieci!)” laureat w konkursie indywidualnym dla nauczycieli w 2011 roku, EDUinspiracje 2013)

Uczniowie niesłyszący zmienili swoja postawę z pasywnej na aktywną. (...) Dla naszego Instytutu ten projekt to prestiż i zwrócenie uwagi na znaczenie edukacji językowej, tak ważnej w przypadku osób niesłyszących, które mają trudności z nauką języków. (...) Osiągnęliśmy w tym roku podium w olimpiadach z języka migowego oraz angielskiego. (Projekt "Sign me English" laureat w konkursie instytucjonalnym w 2013 roku, EDUinspiracje 2013)

Powyższe trzy projekty zgłoszone do nagrody w kategorii ELL musiały spełniać wymagania ustalone przez Komisję Europejską. Przede wszystkim musiały być innowacyjne i mieć wielostronny charakter. Dodatkowo musiały stanowić źródło inspiracji oraz wnosić wartość dodaną do dotychczasowych krajowych praktyk nauczania i uczenia się.

Aby spełnić powyższe kryteria, pomysłodawcy projektów musieli wykazać się wysokim poziomem refleksyjności. Najpierw dokonali oni wnikliwej analizy potrzeb rynku i znaleźli odpowiedniego beneficjenta dla swojego projektu. Dla nauczycielki języka francuskiego były to dzieci i młodzież w młodzieżowym domu kultury, które wykazywały jednoczesne zainteresowania teatrem i nauką JO; dla pomysłodawcy projektu „deDOMO”, przede wszystkim rodzice uczących się dzieci, którzy często nie wierzą w siebie samych jako użytkowników języka obcego i wynieśli ze szkoły lęk przed popełnieniem błędu oraz docelowo dzieci tych rodziców; dla uczestników „Sign me English” uczniowie niesłyszący pragnący komunikować się w amerykańskim i brytyjskim języku migowym. Każdy z projektów jest niewątpliwie innowacyjny, a jego efekty przyczyniają się do udoskonalenia i lepszego zrozumienia procesów nauczania i uczenia się języków. Pierwszy projekt uświadamia, że język obcy może być nieświadomie nabywany, gdy połączy się go z ekspresją głosu, ruchu i gestu podczas przygotowania przedstawień teatralnych. Drugi projekt nasuwa refleksję związaną z rolą rodziców w procesie uczenia się i nauczania ich dzieci. Natomiast ostatni, który zaowocował stroną internetową, dzięki której można nauczyć się amerykańskiego i brytyjskiego języka migowego, pokazuje że proces uczenia się i nauczania może być dostosowany do specjalnych potrzeb uczniów.

$\mathrm{Na}$ potrzeby konkursu EDUinspiracje pomysłodawcy różnych projektów muszą popatrzeć retrospektywnie na swoje dokonania i poddać je ocenie. W ocenie uczestników każdy z powyżej wspomnianych projektów posiada wartość dodaną nie tylko dla środowiska (beneficjentów), ale również dla samego uczestnika projektu np. z refleksji pierwszej uczestniczki wynika, że realizacja projektu przyczyniła się do zmiany w postrzeganiu jej w środowisku jako nauczyciela. 
Warto wspomnieć o jeszcze jednym projekcie współfinansowanym przez Komisję Europejską w ramach Programu "Uczenie się przez całe życie”, a mianowicie Europie bogatej językami. Jest to innowacyjny program, w realizacji którego uczestniczyło ponad 20 krajów i regionów europejskich. Miał on na celu „wymianę dobrych praktyk w promowaniu dialogu międzykulturowego i inkluzji społecznej poprzez nauczanie i uczenie się języków”, „promowanie europejskiej współpracy w opracowaniu polityki językowej i strategii językowych w kilku sektorach edukacyjnych”, oraz "podnoszenie w społeczeństwie świadomości na temat rekomendacji Unii Europejskiej i Rady Europy promujących uczenie się języków i różnorodność językowa w Europie" (Szczuka-Dorna, 2012: 102). Uczestnicy projektu musieli przebadać osiem różnych domen związanych z edukacją językową, ${ }^{9}$ co wymagało od wszystkich uczestników projektu (69 instytucji kształcenia i szkolenia zawodowego oraz 65 uniwersytetów) refleksyjnego i krytycznego podejścia do badanych domen oraz samodzielnego opracowania pytań badawczych i przeanalizowania ogromnej bazy danych z krajów europejskich. Szczuka-Dorna (2012: 102-103) podaje przykładowe pytania badawcze będące przedmiotem refleksji uczestników projektu np.: Jakie korzyści wynikają z umieszczania napisów w filmach w porównaniu ze stosowaniem dubbingu? lub Czy brakuje nauczycieli języków? Odpowiedzi na wszystkie pytania zaowocowały przedstawieniem w dniu 5 marca 2013 roku w Komitecie Społeczno-Ekonomicznym w Brukseli szeregu rekomendacji związanych z rozwojem edukacji językowej w UE. Rekomendacje zgłoszone przez Polskę dotyczyły kształcenia nauczycieli, roli mediów i jakości nauczania kompetencji językowych (Kieszkowska, 2013).

Na koniec warto również powiedzieć kilka słów o wspólnej inicjatywie Komisji Europejskiej i Rady Europy związanej z obchodzonym dnia 26 września Europejskim Dniem Języków (EDJ). To święto języków przyczynia się do zwiększenia refleksyjności i świadomości społecznej na temat bogatego dziedzictwa językowego Europy oraz nauki języków obcych również poza formalnym cyklem. Komitet Ministrów nie narzucił, w jaki sposób należy organizować EDJ. Zaznaczył tylko, że powinien on być zorganizowany w sposób zdecentralizowany, zgodnie z potrzebami państw członkowskich (decyzja Komitetu Ministrów Rady Europy, Strasburg, posiedzenie nr 776 - 6 grudnia 2001 roku). To daje państwom z jednej strony dużą elastyczność w doborze działań, a z drugiej strony obciąża je odpowiedzialnością za ich organizację. Nie-

\footnotetext{
${ }^{9}$ Domeny te były następujące: dokumenty i bazy danych, edukację na etapie przedszkolnym, edukację w szkole podstawowej, średniej i na poziomie wyższym, media audiowizualne i prasę, usługi publiczne i przestrzeń publiczną, biznes.
} 
wątpliwie refleksyjne podejście do selekcji działań i ich treści będzie w dużej mierze decyduje o sukcesie EDJ w danym kraju.

\section{Podsumowanie}

Globalizacja, którą obserwujemy we współczesnych czasach powoduje, że znajomość języków obcych jest priorytetem. Rada Europy oraz Komisja Europejska wyszły naprzeciw oczekiwaniom mieszkańców Europy, dostarczając im narzędzia do efektywnego uczenia się i nauczania języków obcych. Efektywność nie byłaby jednak możliwa bez refleksyjności, która jest promowana w opisowych dokumentach Rady Europy, w programach Komisji Europejskiej oraz wspólnych działaniach tych dwóch instytucji. Refleksyjne podejście do nauki i nauczania języków obcych pozwala na lepsze zrozumienie sposobów uczenia się i nauczania, oraz pokonywanie różnic kulturowych. Stąd też refleksja w kształceniu językowym w Europie stała się paradygmatem, który nie stracił nic na swojej aktualności od czasów Konfucjusza czy Platona.

\section{BIBLIOGRAFIA}

Adams-Tukiendorf, M. 2012. „Rozwijanie refleksji u nauczyciela z wykorzystaniem gry coachingowej POINTS of YOU The coaching game” (w:) PLEJ czyli psycholingwistyczne eksploracje językowe (red. O. Majchrzak). Łódź: Wydawnictwo Uniwersytetu Łódzkiego: 13-26.

Arnold, J. (red.). 1998. Affect in Language Learning. Cambridge: Cambridge University Press.

Boud, D. i D. Walker. 1998. „Promoting reflection in professional courses: the challenge of context" Studies in Higher Education 23(2): 45-59.

Candelier, M. i A. Schröder-Sura. 2012. „Wspieranie rozwoju kompetencji różnojęzycznych i międzykulturowych w klasie szkolnej" Języki Obce w Szkole 4: 4-11.

Candelier, M., A. Camillieri-Grima, V. Castelotti, J-F. De Pietro, I. Lorincz, F. J. Meisner, A. Noguerol, A. Schröder-Sura i M. Molinié. 2012. FREPA. Competences and Resources. Strasbourg: Council of Europe.

Dewey, J. 1933/2007. Democracy and Education. Teddington: Echo Library.

Dörnyei, Z. 2001. Teaching and Researching Motivation. Harlow: Longman.

Farrell,T. 2007. Reflective Language Teaching: From Research to Practice. London: Continuum. Fundacja Rozwoju Systemu Edukacji. 2013. „EDUinspiracje 2013 - Historie sukcesu”. http://issuu.com/frse/docs/eduinspiracje_2013/1 DW 25.11.2013.

Kieszkowska, K. 2013. „Projekt Language Rich Europe - badanie i rekomendacje”. Języki Obce w Szkole 2: 119-122.

Kohonen, P. 2000. „Towards experiental foreign language education” (w:) Experiental Learning in Foreign Language Education (red. V. Kohonen). London: Pearson Education: 78-95. 
Komorowska, H. 2007. Metodyka nauczania języków obcych w Polsce (1957-2007). Warszawa: CODN.

Pawlak, M. 2010. „Designing and piloting a tool for the measurement of the use of pronunciation learning strategies". Research in Language 8: 189-202.

Rada Europy. 2003. Europejski system opisu kształcenia językowego: uczenie się, nauczanie, ocenianie. Warszawa: CODN.

Rada Europy. 2009. Autobiography of Intercultural Encounters. Context, Concepts, and Theories. Strasbourg: Language Policy Division.

Rokoszewska, K. 2012. „The influence of pronunciation learning strategies on mastering English vowels". Studies in Second Language Learning and Teaching 2(3): 391-413.

Schön, D. A. 1987. Educating the Reflective Practitioner. San Fransisco: Jossey Bass.

Smith, A. i S. Lennon. 2011. „Problem solving and critical inquiry in the written and oral reflections of middle school pre-service teachers' classroom experiences". RMLE Online: Research in Middle Level Education 35(1): 1-11.

Szczuka-Dorna, L. 2012. „Europa bogata językami. Trendy w strategiach i praktykach dotyczących wielojęzyczności w Europie”. Języki Obce w Szkole 4: 102-103.

Tranter, G. 2003. „Wspólny europejski obszar odniesienia - Dlaczego? Jak? Co?”. Sprachenservice Erwachsenenbildung 36: 34-45.

Whitmore, J. 2002. Coaching for Performance. GROWing People, Performance and Purpose. London: Nicholas Brealey. 